\title{
THE EXISTENCE OF PESANTREN IN THE DUTCH EAST INDIES GOVERNMENT PRESSURE
}

\author{
Fahruddin \\ Universitas PGRI Yogyakarta \\ Email: fahruddin@upy.ac.id
}

\begin{abstract}
Academic anxiety in this article is that pesantren, as the oldest Islamic religious education institution in the Nusantara, experienced a lot of pressure during the Dutch East Indies Government through the policies it enforced. So the first problem formulation will explain the Zending school policy imposed by the Dutch East Indies Government to compete with pesantren. The second problem formulation will explain the Teacher Ordinance policy to limit pesantren scholars' movement in teaching Islam. From the formulation of the first problem, it is explained that the Dutch East Indies Government's efforts by providing large financial subsidies for priests and zending school students experienced success at the beginning of the period, but failed in the next period. Whereas the second problem formulation explains the imposition of strict administrative requirements before undergoing learning activities, the prohibition of study activities if the pesantren does not meet the stipulated conditions produces more students who dare to oppose colonialism, so the Dutch East Indies Government revoked the Teacher Ordinance in 1928.
\end{abstract}

Abstrak: Kegelisahan akademik dalam artikel ini adalah pesantren sebagai lembaga pendidikan agama Islam tertua di Nusantara mengalami banyak tekanan pada masa Pemerintah Hindia Belanda melalui kebijakan-kebijakan yang diberlakukan. Maka rumusan masalah yang pertama akan menjelaskan kebijakan Sekolah Zending yang diberlakukan oleh Pemerintah Hindia Belanda untuk menyaingi pesantren. Rumusan masalah yang kedua akan menjelaskan kebijakan Ordonansi Guru untuk membatasi gerak bagi para sarjana pesantren dalam mengajarkan agama Islam. Dari rumusan masalah yang pertama menjelaskan bahwa usaha Pemerintah Hindia Belanda dengan memberikan subsidi keuangan yang besar untuk pendeta dan siswa sekolah zending mengalami keberhasilan di awal periode, namun mengalami kegagalan di periode selanjutnya. Sedangkan rumusan masalah yang kedua menjelaskan pemberlakuan persyaratan administrasi yang ketat sebelum menjalani kegiatan belajar, pelarangan kegiatan studi jika pesantren tidak memenuhi ketentuan yang telah ditetapkan justru melahirkan lebih banyak siswa yang berani menentang kolonialisme, sehingga Pemerintah Hindia Belanda mencabut Ordonansi Guru pada tahun 1928.

Keywords: pesantren; Zending schools; teacher ordinances. 


\section{INTRODUCTION}

Initially, the pesantren was a simple religious education institution founded by a kiai considered a religious expert among the Javanese community. Pesantren, which are distinctive educational institutions, have their sub-culture. The pesantren has heavily influenced the community's culture around the pesantren through the influence of the pesantren kiai or all religious education activities followed by the community preserved in the pesantren. Therefore, Javanese society's cultural history cannot be separated from pesantren's role as forming society's religious order. ${ }^{1}$

As Islamic educational institutions that exist until now, Pesantren is not immune from the history of history. Islamic boarding schools are in great demand and have gained great trust for the community to learn Islamic law today, a form of long experience in navigating the changes from time to time in this Nusantara. ${ }^{2}$ At the beginning of the struggle of the kiai to introduce pesantren during the Hindu Buddhist era, they experienced many challenges from local communities who still applied the caste system. Local people considered it inappropriate for the community to be given the right to study their religion without social class boundaries. It is not uncommon for the kiai to have to face the Brahmins in arguments and their superiority.

The kiai struggle with their pesantren encountered a new, more difficult chapter when the Dutch colonial arrived. It is not enough to compete with religious arguments to face a nation familiar with technology and an organized political system. Apart from having a mission to exploit the Nusantara's natural resources, the Dutch colonial nation had a mission to master politics and spread Christian beliefs over time. One form of an effort to spread Christian belief after successfully mastering Indonesian politics is establishing Christian schools. ${ }^{3}$ Several Christian schools were established in the regions, such as Ambon, as many as 16 schools in 1632. A total of 3 Christian schools were also established in Jakarta in 1706. The establishment of these schools was to eliminate Islamic education's influence through the spread of Christian teachings. The Dutch East Indies Government enrolled Dutch and native children to the schools it had founded to become competent workers for the VOC.

When Van den Boss became Governor-General of Jakarta in 1831, he issued a policy that church schools were made into government schools. The departments that manage education and religion are put together. Each region of

1 Moh Sakir, "Pesantren Sebagai Basis Pendidikan Spritual Dalam Pembentukan Karakter Jati Diri Manusia," Cendekia: Journal of Education and Society 13, no. 2 (2016): 171.

2 Irfan Ahmad, "Agama Sebagai Perubahan Sosial: Kristenisasi Di Tobelo 1866-1942," Lembaran Sejarah 11, no. 1 (2017): 83, https://doi.org/10.22146/lembaran-sejarah.23785.

3 I. Djumhur and H. Danasuparta, Sejarah Pendidikan (Bandung: CV. Ilmu, 1976). 
the Residency was established as a Christian religious school. Governor-General Van den Capellen in 1819 AD, took the initiative to plan the establishment of an elementary school for the indigenous population to help the Dutch government. In its circular letter to the Bupati, it was written, "it is deemed important to as soon as possible issue a government regulation which ensures the equality of reading and writing skills for the indigenous population so that it is easier for the indigenous population to comply with national laws and laws."

During the colonial period, Islamic education in Indonesia decreased compared to the previous period (Islamic Kingdom). As colonizers at that time, the Dutch did not care for the development of education in Indonesia, especially Islam, because the Dutch adhered to Christianity, and even the Dutch colonial government tended to obstruct Islamic education in Indonesia. This situation was very reasonable because the Dutch Colonial Government would not last long if Islam were allowed to grow and develop. It is because Islam is a religion that hates all forms of oppression and occupation. To deal with this problem, the Dutch East Indies Government was very grateful to Christian Snouck Hurgronje, who studied Islam.

All policies formed by the Dutch East Indies Government were specifically directed at reducing and defeating Islamic education in Indonesia. The Dutch East Indies government thought that Islamic education would shift its influence when faced with a school model formed according to the times' needs and was closely related to western culture. ${ }^{4}$ In 1890, C. Snouck Hurgronje reported data on the increase in pesantren's spread in the following ten years, but he observed that Christian schools' development seemed to dominate. C. Snouck Hurgronje, as the board of directors for religious policy in the Dutch East Indies government, had the aim of modernizing Indonesia in a western style, not Indonesia with an Islamic tradition.

The political steps imposed by the Dutch East Indies Government to shift the influence of pesantren were through the Zending School policy and the Teacher Ordinance. This article explains the two activities that have been implemented by the Dutch East Indies Government. To explain it, the researcher refers to several literatures. The literature includes: Arifin, Kapita Selecta Pendidikan (Umum dan Agama). Untung, Kebijakan Penguasa Kolonial Belanda Terhadap Pendidikan Pesantren. Ahmad Baso, Pesantren Studies 2a: Kosmopolitanisme Peradaban Kaum Santri di Masa Kolonial. Dwikarwani, Bekti Utaminingsih., Kehidupan Zending Gereformeerd di Surakarta (Studi Sejarah Sosial Budaya). Muhammad Isa Anshory, Mengkristenkan Jawa: Dukungan Pemerintah Kolonial Belanda terhadap Penetrasi Mmisi Kristen. Aqib Suminto, Politik Islam Hindia

${ }^{4}$ Harry J. Benda, Bulan Sabit Dan Matahari Terbit Islam Indonesia Pada Masa Pendudukan Jepang (Jakarta: PT. Dunia Pustaka Jaya, 1985). 
Belanda. Subroto, Strategi Snouck Mengalahkan Jihad di Nusantara. Anam, Choirul., Pertumbuhan dan Perkembangan NU. Farid Setiawan, Kebijakan Pendidikan Muhammadiyah terhadap Ordonansi Guru. Farid Setiawan, Kebijakan Pendidikan Muhammadiyah pada Masa Kolonial Belanda: 19111942. These literature reveals a lot about the Dutch East Indies Government's education policy to shift the existence of pesantren in the Nusantara.

Apart from that literature, the researcher also refers to other references such as the writings of Baudet and Brugmans, Politik Etis dan Revolusi Kemerdekaan. Baudet and Brugmans reveal data on zending schools that have been established by the Dutch East Indies Government. The archive strengthens the data regarding the number of Zending Schools in ANRI, namely Staatsblad van Netherlands Indie 1938 Number 511. It also uses other literature to describe the Teacher Ordinance politics through the ANRI archive collection, Staatsblad 925 Number 219 of 1905, which proves that the Dutch East Indies Government-issued Teacher Ordinance policies to respond to developments in Islamic religious education.

The academic anxiety in this paper is why the Dutch East Indies Government considered pesantren needed to be eliminated by creating the Zending School in 1900 and being suppressed through the Teacher Ordinance policy in 1900, even though the Dutch East Indies Government had been able to control the government in the Nusantara since 1813. The research problems of this research are as follows. First, how is the pesantren's existence when the Dutch East Indies government imposed the Zending School politics? The purpose of the first problem is to reveal Islamic boarding schools' existence amid the Zending School politics. Meanwhile, the second problem formulation aims to determine the kiai and students' attitude in responding to the Teacher Ordinance policy, which seeks to limit the pesantren's movement. The approach used by the researcher is a religious approach to explain the thoughts and attitudes of pesantren scholars in response to pressure from the Dutch East Indies Government. Also, a cultural approach is used to describe the traditional educational traditions that run in pesantren.

\section{THE EXISTENCE OF PESANTREN IN THE DUTCH EAST INDIES GOVERNMENT'S INTERVENTION}

Pesantren is an Islamic educational institution that has consistently spread Islamic law and opposes colonialism carried out by the Dutch East Indies Government since the Nusantara annexed it. Pesantren, through recitation, always instils the embryo of patriotism and religious enthusiasm in the students. As an Islamic education institution, pesantren was born as a "training center" and "cultural 
center," which was trusted by indigenous people who embrace Islam. De facto, the Dutch East Indies Government could not deny the role of the pesantren. ${ }^{5}$

The pesantren's resistance to the Dutch East Indies Government was a form of pesantren's effort in maintaining its religio-cultural identity from the attempt to penetrate the secular education system introduced by the colonial nation. The resistance is carried out by the pesantren in two ways, namely secretly and openly. Hidden resistance was seen through the pesantren's efforts to be conservative and defensive of all forms of Dutch East Indies Government policies. Meanwhile, open resistance is manifested through non-cooperative attitudes and always ignites a spirit of anti-colonialism. ${ }^{6}$ These efforts emerged as pesantren responses to strengthening Western culture's penetration and the interventionist policies carried out by the Dutch East Indies Government towards indigenous Muslim communities. $^{?}$

The indigenous people's spirit in fighting for Indonesian independence flared up in various regions to respond to the Dutch East Indies Government's supremacy. This spirit triggered the pesantren, which initially opposed secretly, began to dare to show open resistance. This involvement shows the awareness of "proto nationalism" among the pesantren, which later gave birth to a strong force of nationalism so that the function of the pesantren, which was originally an Islamic religious education institution, has become a center of anti-Dutch sentiment.

The struggle of the santri intersected with the Dutch East Indies Government and the nationalists who were pro with the Dutch East Indies Government. Many nationalists did not agree with the development of education that was being fought for through pesantren. ${ }^{8}$ For example, Gunawan Mangoenkoesumo once proposed at the Boedi Oetomo Congress in Yogyakarta in 1930 to formulate a pesantren monitoring program. This proposal was later rejected by the congress participants thanks to a statement made by dr. Soetomo. dr. Soetomo presents arguments that show a supportive attitude towards the sustainability of the pesantren.

Sutan Takdir Alisyahbana, one of the pro-colonial figures, has shown a suspicious attitude towards pesantren. Alisyahbana's destiny has heavily criticized the pesantren cultural polemic. He argues that "returning to pesantren means returning to anti-intellectualism, anti-individualism, antiegoism, anti-

5 H.M. Arifin, Kapita Selekta Pendidikan : (Islam Dan Umum), 4th ed. (Jakarta: Bumi Aksara, 2000).

${ }^{6}$ Mahmud Arif, Pendidikan Islam Transformatif(Yogyakarta: LKiS, 2008).

7 Slamet Untung, "Kebijakan Penguasa Kolonial Belanda Terhadap Pendidikan Pesantren," Edukasia Islamika 11, no. 1 (2013).

8 Ahmad Baso, Al-Jabiri, Eropa Dan Kita, 2 Ed (Tangerang: Pustaka Afid, 2017). 
materialism." Several indigenous figures who were anti-pesantren concluded that if pesantren were to be implemented again in the modern era, Indonesia's traditions would not progress. Traditions in Indonesia would remain a tradition full of ignorance. ${ }^{9}$

The debate about pesantren has been carried out by those close to the media world, making public opinions. Those who are opposed to pesantren often express their opinions through writings and then disseminate them to the general public. Those who are pro towards pesantren also always fight back through strong and basic arguments through the media, and those who were pro towards pesantren, among others, dr. Soetomo, dr. Wahidin Soedirohoesodo, Ki Hadjar Dewantara, and Sutopo Adiseputro. Meanwhile, those who oppose the pesantren include Sutan Takdir Alisyahbana, Notosoeroto, and Gunawan Mangunkusumo. ${ }^{10}$

The attitude of anti and suspicion towards pesantren is on the mind of every Dutch person. They hate Muslims because they have high concerns about the emergence of great power from Indonesia's Muslims. The Dutch East Indies government was worried that there would be rebellions like the one carried out by the Muslims led by Prince Diponegoro in the Java War in 1825-1830. Snouck Hurgronje, who always observes the development of Islam in Indonesia, stated that "the development of Muslim community worship cannot be avoided, so people are still free to worship, but what needs to be supervised in their education. Because it is through education, such as pesantren that anti-colonial attitudes will be taught. "

At the suggestion of Snouck Hurgronje, the Dutch East Indies Government made a policy specifically designed to fight indigenous people from among the pesantren. The policy was to separate Islam as a religion and Islam as a political doctrine. The Dutch East Indies Government needed to activate indigenous people from among the customary stakeholders to carry out this policy. It was believed that the group of customary holders who still have their ancestral traditions would oppose the santri. The difference in tradition between the indigenous people who still adhere to their ancestors' traditions and the pesantren would facilitate the Dutch East Indies Government's efforts to narrow the Muslims' movement. ${ }^{11}$

The Dutch East Indies government began to establish close relations with the priyai group. Snouck Hurgronje established good communication with the priyai through the Indonesian-Dutch cultural cooperation. Pamongpraja was

9 Ahmad Baso.

${ }^{10}$ Ahmad Baso, Pesantren Studies 2a: Kosmopolitanisme Peradaban Kaum Santri Di Masa Kolonial (Jakarta: Pustaka Afid, 2012).

${ }^{11}$ Untung, "Kebijakan Penguasa Kolonial Belanda Terhadap Pendidikan Pesantren." 
the target party for Snouck Hurgronje to always work against the Islamization movement. The Dutch East Indies government educated children from priyai circles with western educators. The education provided is not directed at training free-thinking and desiring to be independent, but education was only used as a tool to protect customs and as an instrument to fight against the movement of the santri.

\section{Zending Policy}

Since the implementation of the Ethical Policy, the Dutch East Indies Government began to strengthen its influence through education policies. The Dutch East Indies Government established the education policy aimed at the interests of the Dutch state's colonial power in the Nusantara and sought interventions in education other than those established by the Dutch East Indies Government, one of which was the pesantren. Pesantren, which were Islamic religious education institutions led by kiai, had been recognized by the Dutch East Indies Government as an educational institution that teaches jihad against the colonialists. For this reason, the Dutch East Indies Government was trying to exploit the entire natural resource assets of the Nusantara and had the aim of spreading Christianity. ${ }^{12}$

The Dutch East Indies government collaborated with the missionary organization Zending Govermeerd to evangelize through the Educational Institution. The granting of permits for the establishment of Christian schools made it clear that the Dutch East Indies Government was increasingly open to Christianization activities in the Nusantara. The Dutch East Indies government compiled the best curriculum for schools' smooth distribution to attract many students from both aristocratic and ordinary people.

The politics of association began to be applied by the Dutch East Indies Government in developing schools based on Snouck Hurgronje. Dutch supremacy over the indigenous people should be highlighted in history lessons. The Dutch East Indies Government's role towards regional progress in Indonesia must always be seen in history textbooks. History textbooks at every level of school education became a tool that exaggerated the name of the Dutch East Indies Government (Netherlando centris). ${ }^{13}$ There was a violation of private schools, which the Dutch East Indies government referred to as "Wilde Scholen." This

${ }^{12}$ Aprilia Pradewi, Leo Agung S., and Dadan Adi Kurniawan, "Peran Zending Dalam Pendidikan Di Surakarta Tahun 1910-1942 Dan Relevansinya Dengan Materi Sejarah Pendidikan3," CANDI 19, no. 2 (2019): 154-72.

${ }^{13}$ Tjandrasasmita, Arkeologi Islam Nusantara (Jakarta: Kepustakaan Populer Gramedia, 2009). 
opposition arose from educated community figures who later gave rise to Islamic boarding schools' growth in Indonesia. ${ }^{14}$

Ethical Policy was meant to promote Christian ideals. Ethical Policy was a framework that contains the consolidation of Christianity in Indonesia. It did reflect an important shift in the Dutch colonial government's strategy towards the Christianization of Indonesia. This policy showed that neutrality in matters of religion is an illusion. ${ }^{15}$ For political reasons, the Dutch East Indies Government separated Islamic education from the general education system developed. The separation of the system was a logical consequence of the Dutch East Indies Government's anti-Islamic policy. ${ }^{16}$ Since the separation, Islamic education institutions had taken their path by breaking away from the governorship, sticking to their traditions, although remaining open to change.

Indigenous peoples who were colonized slowly began to leave traditions that were considered outdated and no longer worth preserving. ${ }^{17}$ As the oldest educational institution in Indonesia, Pesantren did not escape colonial pressure through the established educational institutions. The colonial legacy of formal schools emerged, which began to be of great interest to the indigenous people. These formal schools also received full support from the government with a standard curriculum system that was mandatory for every formal education institution. ${ }^{18}$

Education is something very important for indigenous people. People know religious values through education. Through education, the public was also introduced to worship and good social behavior in accordance with religious guidance. ${ }^{19} \mathrm{On}$ this basis, the evangelists took this gap to facilitate Christianization in the Dutch East Indies. To carry out its mission, the evangelists were given education first. The evangelists were gathered in the NZV or Nederlansh Zendeling Vereeniging organization. At first, they were not a teacher but a priest. After the division of tasks, the Zendeling was then equipped with Christianity and other evangelistic knowledge. ${ }^{20}$

${ }^{14}$ Harry J. Benda, Bulan Sabit Dan Matahari Terbit Islam Indonesia Pada Masa Pendudukan Jepang.

${ }^{15}$ Alwi Shihab, Membendung Arus Respons Gerakan Muhammadiyah Terhadap Penetrasi Misi Kristen Di Indonesia (Bandung: Mizan, 1998).

${ }^{16}$ Karel A. Steebrink, Pesantren Madrasah Sekolah Pendidikan Islam Dalam Kurun Modern (Jakarta: LP3ES, 1994).

${ }^{17}$ Ahmad Baso, Al-Jabiri, Eropa Dan Kita, 2 Ed.

${ }^{18}$ Ahmad Natsir, "Identitas Poskolonialisme Pesantren Modern," Cendekia 17, no. 2 (2019): 203-18.

${ }^{19}$ Erwin Yudi Prahara, "Pengaruh Pendidikan Agama Pada Anak Dalam Keluarga Beda Agama Di Desa Klepu Sooko Ponorogo," Cendekia: Jurnal Kependidikan Dan Kemasyarakatan 14, no. 1 (2016): 19.

${ }^{20}$ Soetarman, Dari Musa Dan Segala Nabi (Jakarta: BPK Gunung Mulia, 2003). 
Christian churches joined the missionary community, so Zending, who came to Java, was led by Zending Gofermeerd. Churches in Java were tied to churches in the Netherlands, as is Zending. ${ }^{21}$ Van Andel and his colleagues initiated the permit to establish a Christian school in Java as happened in Surakarta through a group they had formed, namely "Vereniging tot Oprichting en Istandhoyding van Christelyke Schoolen en Internaten te Surakarta" which was held on July 25, 1916, in Surakarta. Their application was submitted to the Governor-General in the Dutch East Indies with the knowledge of the Resident of Surakarta. ${ }^{22}$

The Christian school was divided into two groups: those specifically intended for European children and indigenous communities. Besides introducing Christian beliefs, the curriculum also introduced western culture, such as how to communicate, eat, dress, and socialize, and so forth. Dutch was used as the main student at every level of school. It was also used in daily communication with teachers and interaction with fellow students. Dormitories for compulsory housing for teachers and students were also provided, and Dutch must be applied daily. These rules were directed so that the student community was fully acquainted with western cultures and left the local cultures. Also, Zending School facilitated job opportunities for alumni in various fields. ${ }^{23}$

The main purpose of the Zending school was to spread the teachings of Christian beliefs. It was also funded by the Dutch East Indies Government in its operations. The Dutch East Indies government always supported the development of the Zending school. Rapid progress could be seen in several areas, such as Surakarta. In 1930 in Surakarta, 20 Zending schools were established in Margoyudan, Villapark (near Pasar Legi), Sidokare, Jebres, Kerten, Gemblegan, Danukusuman, Kawatan, Gilingan, and Manahan. ${ }^{24}$ The distribution of the construction of this school was also well regulated so that it was built in a place close to the pesantren to be able to attract the interest of the surrounding Muslim community to send their children to schools established by the Dutch East Indies Government.

The Dutch East Indies Government's discriminatory policies began to appear after several Christian schools had been established. The Dutch East Indies government provided subsidies for the operation of Christian schools. All operational needs could be fulfilled through this subsidy fund. In contrast to

${ }^{21}$ Bekti Dwikarwani Utaminingsih, "Kehidupan Zending Gereformeerd Di Surakarta (Studi Sejarah Sosial Budaya)” (Universitas Negeri Sebelas Maret, 1998).

22 "Besluit Gubernur Jendral Di HIndia Belanda Kepada Pendeta Utusan Di Surakarta" (Jakarta, 1916).

${ }^{23}$ Dwikarwani Utaminingsih, "Kehidupan Zending Gereformeerd Di Surakarta (Studi Sejarah Sosial Budaya)."

${ }^{24}$ H. Baudet and I.J. Brugmans, Politik Etis Dan Revolusi Kemerdekaan (Jakarta: YOI, 1987). 
Islamic-based schools such as pesantren, the Dutch East Indies Government did not provide financial assistance to these institutions. Subsidies were still given to Islamic schools that are not Islamic boarding schools, namely private schools established by native Muslim communities, but the subsidies received were very small compared to those received by Christian schools.

List of subsidies provided by the Dutch East Indies Government to Christian and Islamic schools ${ }^{25}$

\begin{tabular}{|c|c|c|}
\hline Year & Christian School & Islamic school \\
\hline 1936 & $\mathrm{f} 686.100,-$ & $\mathrm{f} 7.500,-$ \\
\hline 1937 & $\mathrm{f} 686.200,-$ & $\mathrm{f} 7.500,-$ \\
\hline 1938 & $\mathrm{f} 696.100,-$ & $\mathrm{f} 7.500,-$ \\
\hline 1939 & $\mathrm{f} 844.000,-$ & $\mathrm{f} 7.600,-$ \\
\hline
\end{tabular}

The subsidy for Christians in the amount of $\mathrm{f} 696,100$, - in 1938 consisted of personal expenses of $f 633,200$, - and equipment costs of $f 62,900$, - Personal costs include salaries and special allowances for pastors of $\mathrm{f} 598,000$, assignment and child allowances of $f 15,900$, allowances for official purposes of $f 7,000$, and other personal costs of $f 12,300,-$. The details of equipment costs include training costs of $\mathrm{f} 900,-$, student medical care costs of $\mathrm{f} 300,-$, maintenance costs of Church Council offices of $f 900,-$, local government telegram costs of $f 800$, -, and travel and residence as much as $\mathrm{f} 60,000,-{ }^{26}$

The subsidy data shows that the Dutch East Indies Government paid more attention to Christian schools than private Islamic schools. No data shows the provision of subsidies by the Dutch East Indies Government for pesantren. The Dutch East Indies government had monitored private Islamic schools that were deemed not to have a major impact on developing a better movement for students and society. The Dutch East Indies Government specifically monitored Pesantren because, from the start, the Dutch East Indies Government wanted to eliminate the institution led by the kiai, one of which was by not providing subsidies to pesantren so that the pesantren could not develop so that people believed more in other Islamic schools or Christian schools that seemed increasingly developing.

Pesantren under Zending's policy was an insistence on maintaining the consistency of their religious scholarly traditions. The kiai was aware of the efforts of the Dutch East Indies Government through the Zending school program. Even though the pesantren did not develop as fast as the Zending school, the kiai never stopped teaching the students to maintain Islam's honor and cultivate the

${ }^{25}$ Deliar Noer, Gerakan Islam Di Indonesia 1900-1942 (Jakarta: LP3ES, 1996).

${ }^{26}$ Muhammad Isa Anshory, Mengkristenkan Jawa: Dukungan Pemerintah Kolonial Belanda Terhadap Penetrasi Mmisi Kristen (Karanganyar: Pustaka Lir-ilir, 2013). 
spirit of patriotism of the Indonesian nation. The Dutch East Indies government realized the persistence of the kiai in fighting for their pesantren institutions and their persistence in raising the seeds of patriotism for the santri. Because of this, the Zending program was continued until it stopped after Japanese influence came to Indonesia.

\section{Teacher Ordinance}

It was stated in Staatsblad 925 Number 219 of 1905 that the Dutch East Indies Government issued a Teacher Ordinance policy regarding the teaching of Islam. The Teacher Ordinance policy was enforced through Ispectoral Indigenous Education to limit the space for kiai in Islamic boarding schools and religious teachers in private schools. The policy emerged on the initiative of Snouck Hurgronje to regulate the Islamic religious education system in Indonesia. The teacher ordinance, which was first issued in 1905, requires every Islamic religious teacher to ask for and obtain permission before conducting religious teaching. ${ }^{27}$

The teacher ordinance in 1905 was declared valid for Java Madura except for Yogyakarta and Surakarta. The contents of this teacher ordinance included:

1. A teacher of Islam was only allowed to teach if he has obtained permission from the Regent.

2. This permit was only granted when the religion teacher could be judged as a good person, and the lessons given did not conflict with the security of public order.

3. The Islamic religious teacher must fill in a list of students, in addition to having to explain the subjects being taught.

4. The Regent or the competent authority might check the list at any time.

5. Islamic religious teachers could be sentenced to a maximum of eight days or a maximum fine of twenty-five rupiahs if they are found to be teaching without permission or fail to complete/send the list; or unwilling to show the list to the competent authorities, objecting to providing information, or being reluctant to show the list to the competent authorities, objecting to providing information, or being unwilling to be examined by the competent authorities.

6. The permit could also be revoked if it turns out that the religious teacher has repeatedly violated the rules or is deemed to have misbehaved.

For educational institutions with good administrative management, the Teacher Ordinance policy's demands could be implemented properly, but for educational institutions that do not yet have a good administrative management system, the Teacher Ordinance policy demands were difficult to fulfil. Besides,

${ }^{27}$ Aqib Suminto, Politik Islam Hindia Belanda (Jakarta: LP3ES, 1985). 
many religious teachers could not read Latin characters, while it was very rare for them to have a writing machine to fill out the various lists of reports. Of course, this policy hindered the practice of learning every day because the kiai and the Ustadz had to make permits, which was not an easy process. At that time, the kiai and Ustadz saw this policy to hinder Islamic learning development. ${ }^{28}$

The second ordinance policy was issued in 1925 . The ordinance policy was formulated to narrow the movement of Islamic education further. ${ }^{29}$ The Dutch East Indies government issued a policy that not all kiai and ustadz were allowed to teach Islam. Responding to the policy, KH. Hasyim Asy'ari as the caretaker of the Tebu Ireng Islamic Boarding School showed his opposition to the Dutch East Indies Government's policies. KH. Hasyim Asy'ari, together with Islamic boarding school clerics in the Java and Madura regions, urged that the ordinance policy be abolished. This opposition movement also occurred in Sumatra, which was led by Islamic boarding school clerics. ${ }^{30}$

Opposition against pressure from the Dutch East Indies Government policy also emerged in Surakarta. The Mambaul Ulum Islamic Boarding School, which was built by Susuhunan Pakubuwono, quickly responded to pressure from Zending Education through updating the curriculum of the Mambaul Ulum Islamic Boarding School. General subjects that previously did not exist were included for the students to study. This response was carried out in 1906 because the zending movement was increasingly active through updating modern subjects and curricula to gain public sympathy. ${ }^{31}$

The resistance movement of the pesantren kiai has never subsided. The Teacher Ordinance policy has been adhered to by several educational institutions that are administratively organized, such as Taman Siswa, led by Ki Hajar Dewantara, and Muhammadiyah, led by KH. Ahmad Dahlan. ${ }^{32}$ It was different from pesantren ulama, who firmly held that the policy was only a form of politics by the Dutch East Indies Government to eliminate Islam's scientific tradition and try to make ulama's role not seen by the public. ${ }^{33}$ Pesantren continued to carry out their recitation activities as usual, regardless of the Teacher Ordinance rules.

28 Choirul Anam, Pertumbuhan Dan Perkembangan NU(Surabaya: Aksara Mulia, 2010).

${ }^{29}$ Farid Setiawan, "Kebijakan Pendidikan Muhammadiyah Terhadap Ordonansi Guru," Jurnal Pendidikan Islam 3, no. 1 (2014).

${ }^{30}$ Anisatul Khoir Aprilia, "Peran Nahdlatul Ulama Dalam Pergerakan Nasional Indonesia Tahun 1926-1945” (Universitas Jember, 2017).

${ }^{31}$ Toto Suharto, "Bayn Ma'had Tebuireng Wa Madrasat Manba' al'UUlūm: Dirāsah Tārīkhīyah 'an Nash'at Mafhūm 'Al-Madrasah F̄̄ al-Ma'Had,”' Studia Islamika 21, no. 1 (2014).

${ }^{32}$ Farid Setiawan, "Kebijakan Pendidikan Muhammadiyah Pada Masa Kolonial Belanda: 1911-1942” (UIN Sunan Kalijaga, 2013).

${ }^{33}$ Anzar Abdullah, "Perkembangan Pesantren Dan Madrasah Di Indonesia Dari Masa Kolonial Sampai Orde Baru,” Paramita: Historical Studies Journal 23, no. 2 (2013): 193-207. 
In 1928 the Dutch East Indies Government revoked the Teacher Ordinance policy because it was considered that pesantren had not subsided through this effort. Pesantren was able to show courage in opposing the policies of the Dutch East Indies Government. The emphasis on the sake of emphasis added to jihad's spirit among the kiai and santri until the Dutch colonialism ended after Indonesia's independence on August 17, 1945.

\section{CONCLUSION}

As Islamic religious education institutions were born since Islam's inception in the Nusantara, pesantren still exists and is growing. This development is achieved through the pesantren ulama's struggle, who always persistent in opposing all forms of pressure from the Dutch East Indies Government. The pesantren that the Dutch East Indies Government believed was an institution that gave birth to resistance seeds was considered dangerous. For this reason, the Dutch East Indies Government issued a zending school policy and the Teacher Ordinance. The two policies were considered the best way by creating competition for Christian education and limiting the space for pesantren ulama's movement. However, these two policies did not dampen the pesantren ulama's enthusiasm to always strive for the pesantren's existence. The ulama's resistance through always istiqomah in teaching Islamic sharia without ignoring all the Zending School policies and the Teacher Ordinance has succeeded in showing the Dutch East Indies Government's failure until the Teacher Ordinance policy was repealed in 1928. 


\section{REFERENCES}

Abdullah, Anzar. "Perkembangan Pesantren Dan Madrasah Di Indonesia Dari Masa Kolonial Sampai Orde Baru." Paramita: Historical Studies Journal 23, no. 2 (2013): 193-207.

Ahmad Baso. Al-Jabiri, Eropa Dan Kita, 2 Ed. Tangerang: Pustaka Afid, 2017.

- Pesantren Studies 2a: Kosmopolitanisme Peradaban Kaum Santri Di Masa Kolonial. Jakarta: Pustaka Afid, 2012.

Ahmad, Irfan. "Agama Sebagai Perubahan Sosial: Kristenisasi Di Tobelo 18661942.” Lembaran Sejarah 11, no. 1 (2017): 83.

Alwi Shihab. Membendung Arus Respons Gerakan Muhammadiyah Terhadap Penetrasi Misi Kristen Di Indonesia. Bandung: Mizan, 1998.

Anam, Choirul. Pertumbuhan Dan Perkembangan NU. Surabaya: Aksara Mulia, 2010.

Anshory, Muhammad Isa. Mengkristenkan Jawa: Dukungan Pemerintah Kolonial Belanda Terhadap Penetrasi Mmisi Kristen. Karanganyar: Pustaka Lir-ilir, 2013.

Aprilia, Anisatul Khoir. "Peran Nahdlatul Ulama Dalam Pergerakan Nasional Indonesia Tahun 1926-1945.” Universitas Jember, 2017.

Aqib Suminto. Politik Islam Hindia Belanda. Jakarta: LP3ES, 1985.

Arif, Mahmud. Pendidikan Islam Transformatif. Yogyakarta: LKiS, 2008.

Arifin, H.M. Kapita Selekta Pendidikan : (Islam Dan Umum). 4th ed. Jakarta: Bumi Aksara, 2000.

Baudet, H., and I.J. Brugmans. Politik Etis Dan Revolusi Kemerdekaan. Jakarta: YOI, 1987.

"Besluit Gubernur Jendral Di HIndia Belanda Kepada Pendeta Utusan Di Surakarta." Jakarta, 1916.

Djumhur, I., and H. Danasuparta. Sejarah Pendidikan. Bandung: CV. Ilmu, 1976. 
Dwikarwani Utaminingsih, Bekti. "Kehidupan Zending Gereformeerd Di Surakarta (Studi Sejarah Sosial Budaya).” Universitas Negeri Sebelas Maret, 1998.

Farid Setiawan. "Kebijakan Pendidikan Muhammadiyah Pada Masa Kolonial Belanda: 1911-1942.” UIN Sunan Kalijaga, 2013.

—_. "Kebijakan Pendidikan Muhammadiyah Terhadap Ordonansi Guru." Jurnal Pendidikan Islam 3, no. 1 (2014).

Harry J. Benda. Bulan Sabit Dan Matahari Terbit Islam Indonesia Pada Masa Pendudukan Jepang. Jakarta: PT. Dunia Pustaka Jaya, 1985.

Karel A. Steebrink. Pesantren Madrasah Sekolah Pendidikan Islam Dalam Kurun Modern. Jakarta: LP3ES, 1994.

Natsir, Ahmad. "Identitas Poskolonialisme Pesantren Modern." Cendekia 17, no. 2 (2019): 203-18.

Noer, Deliar. Gerakan Islam Di Indonesia 1900-1942. Jakarta: LP3ES, 1996.

Pradewi, Aprilia, Leo Agung S., and Dadan Adi Kurniawan. "Peran Zending Dalam Pendidikan Di Surakarta Tahun 1910-1942 Dan Relevansinya Dengan Materi Sejarah Pendidikan3." CANDI 19, no. 2 (2019): 154-72.

Prahara, Erwin Yudi. "Pengaruh Pendidikan Agama Pada Anak Dalam Keluarga Beda Agama Di Desa Klepu Sooko Ponorogo.” Cendekia: Jurnal Kependidikan Dan Kemasyarakatan 14, no. 1 (2016): 19.

Sakir, Moh. "Pesantren Sebagai Basis Pendidikan Spritual Dalam Pembentukan Karakter Jati Diri Manusia." Cendekia: Journal of Education and Society 13, no. 2 (2016): 171.

Soetarman. Dari Musa Dan Segala Nabi. Jakarta: BPK Gunung Mulia, 2003.

Tjandrasasmita. Arkeologi Islam Nusantara. Jakarta: Kepustakaan Populer Gramedia, 2009.

Toto Suharto. “Bayn Ma'had Tebuireng Wa Madrasat Manba' al-'Ullm: Dir】sah Tārikhīyah 'an Nash'at Mafh $\llbracket m$ 'Al-Madrasah Fl al-Ma'Had.'” Studia Islamika 21, no. 1 (2014).

Untung, Slamet. "Kebijakan Penguasa Kolonial Belanda Terhadap Pendidikan Pesantren.” Edukasia Islamika 11, no. 1 (2013). 